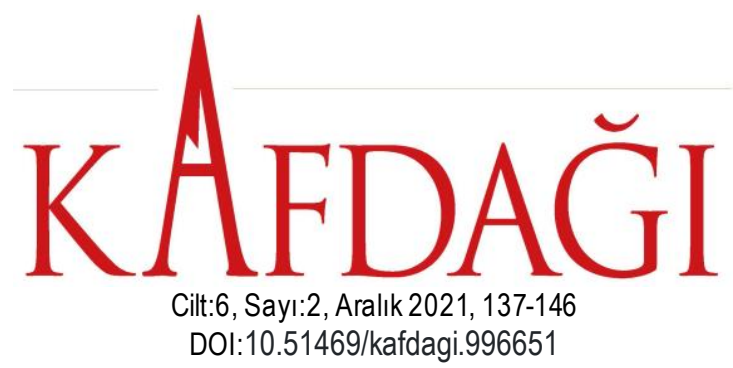

Gönderim Tarihi: 16.09.2021

Kabul Tarihi:28.11.2021

\title{
THE THINGS PANDEMIC REMINDS US: A SOCIODEMOGRAPHIC ANALYSIS OF ALTRUISM
}

Pandeminin Hatırımıza Getirdikleri: Diğerkamlık Üzerine Sosyo-Demografik Analizler

Hasan Giray ANKARA

Dr. Öğr. Üyesi, Sağlık Bilimleri Üniversitesi

Sağlık Bilimleri Enstitüsü

hg.ankara@sbu.edu.tr

ORCID ID: 0000-0002-8058-1428

Hakan DEĞERLi

Öğr. Gör., Bilecik Şeyh Edebali Üniversitesi

Sağlık Hizmetleri Meslek Yüksekokulu

hakan.degerli@bilecik.edu.tr

ORCID ID: 0000-0002-7268-4320

Havvana DEĞERLi

Doktora Öğr., Sağlık Bilimleri Üniversitesi

Sağlık Bilimleri Enstitüsü

hhavvanadegerli@gmail.com

ORCID ID: 0000-0002-5590-7211

Çalışmanın Türü: Araştırma

\begin{abstract}
There has been limited research in revealing the socioeconomic determinants of altruism during the COVID-19 pandemic. We examine socio-demographic and socio-economic determinants of altruism in Turkish society during the COVID-19 pandemic in the study. Exploiting the secondary data of 933 individuals we employ multivariate linear regression and quantile regression designs to identify the factors affecting the altruism of the individuals living in Turkey. According to the research findings, we detect that the altruism level of Turkish society is already high. In addition, we reveal that altruism is determined by gender, having siblings, religious sensitivity, and the place of residence. On the other hand, no significant impacts of living with people who are more vulnerable to pandemics (i.e., elderly, pregnant, and those with a chronic disease) are observed on the level of altruism of the individuals.
\end{abstract}

Keywords: Altruism, COVID-19, Pandemic, Sociodemographic Determinants

$\ddot{O} z$

COVID-19 salgını süresince diğerkamlı̆̆ın sosyo-ekonomik belirleyicilerini ortaya koyma 


\begin{abstract}
konusunda az sayıda araştırma yapılmıştır. Bu çalışma, COVID-19 pandemisi sürecinde Türk toplumunda bireylerin diğerkamllk düzeylerine etki eden sosyo-demografik ve sosyoekonomik belirleyicilerini araştırmaktadır. Türkiye'de yaşayan 933 bireyin ikincil verileri kullanılarak, bireylerin diğerkamlığını etkileyen faktörleri belirlemek için çok değişkenli lineer regresyon ve dăğllm regresyon tahminleri gerçekleştirilmiştir. Çalı̧̧ma bulgularına göre Türk toplumunun diğerkamlık seviyesinin yüksek olduğu tespit edilmiştir. Bununla birlikte cinsiyet, kardeş sahibi olma, dini hassasiyetlere sahip olma ve yaşanılan yerin kişinin diğerkamlık seviyesi üzerinde etkili olduğu tespit edilmiştir. Öte yandan, salgın hastalığa karşı daha savunmasız olan insanlar (yaşlılar, hamileler ve kronik hastalığ olanlar) ile birlikte yaşamanin diğerkamlı seviyeleri üzerinde anlamlı etkileri bulunamamıştır.
\end{abstract}

Anahtar Kelimeler: Diğerkamlık, COVID-19, Pandemi, Sosyo-demografik Belirleyiciler.

\title{
1. Introduction
}

COVID-19 has become a pandemic shortly after the first case appeared (WHO, 2020a). In addition to the physical and psychological consequences, the concepts such as "social distance", "isolation" or "quarantine" have had major impacts on our daily lives (Arin En sarioglu, 2020). As there has been no treatment yet, World Health Organization (WHO, 2020b) has recommended some measures that may be effective to prevent the spread. Since the infection has potential to affect not only the infected individuals themselves but also the others, voluntary self-isolation is considered as one of the most important tools to protect the individuals from COVID-19 spread (WHO, 2020c). In this context, voluntarily isolating behaviour of oneself for others can be considered as altruistic behaviour. Therefore, we believe that voluntary self-isolation as a preventive behaviour against the infection may be related to altruism levels of individuals. Because of this, we identify socio-demographic and socio-economic factors affecting altruism among Turkish society in this study. By doing this, we aim to contribute in understanding the motivations of preventive behaviou rs during pandemics.

Although altruism is a subject of psychology or philosophy (Scott and Seglow, 2007), it has always been a subject of interest in various fields including sociology and economics (Karadag and Mutafcilar, 2009). Despite different fields of study have different perspectives, the essence of altruism concept is accepted as universal (Scott and Seglow, 2007). The concept of altruism implies donation, sharing, cooperation, helping and positive social behaviour (Monroe, 1996). It is defined as the behaviour that one acts benevolently with the aim of others' benefit without expecting any reward (Mateer and Willover, 1994). 
The reasons of exhibiting altruistic behaviours have widely been investigated in different fields of research. The literature bears the findings regarding origins of altruistic behaviours as well as their determinants. This ranges from an innate disposition to socialization and tangible reward. In this respect, explain the factors affecting altruistic behavior, many factors should be considered rather than a single explanatory variable (Monroe, 1996). It is aimed to reveal the socio-demographic and socio-economic factors that affect the altruism levels in this study.

\section{Background}

The concept of "altruism" was introduced by Auguste Comte (1875). It is derived from the Latin word "alterihuic" meaning that "for someone else" (Gormley, 1996). Altruism is explained as the motivation al situation with the aim of increasing someone else's benefit (Batson, 2014). In other saying, it is a behaviour to help someone else without expecting a reward (Bukatko and Daehler, 2012; Leeds, 1963; Smith, Organ and Near, 1983; Levey-Bruhl, 1970). It involves helping to others voluntarily (Cohen, 1972; Leeds, 1963; Podsakoff and MacKenzie, 1994) and sacrificing one's own interests in favour of others (Boehm, 1979; Zettler and Hilbig, 2010).

We believe that voluntary self-isolation during COVID-19 $\mathrm{p}$ ande mic is a good example of altruistic behaviour since individuals' volu ntary selfisolating behaviour (even they may be relatively less vulnerable to the infection) is related to protect not only themselves but also their (probably more vulnerable) environment against the spread.

There has been a great deal in the literature that altruism is fundamentally based on religion as it is widely suggested that religions advise people to be kind to others and to help them (Monroe, 1996; Khalil, 2004). Because of this, we include individuals' religious sensitivities in the analyses to survey the effect of religious sensitivity on altruism. Additionally, there have been studies suggesting that altruism is based on moral philosophy (Ross, 1993; Khalil, 2004). Accordingly, altruistic behaviour is the application of the thought of "treat others the way you want others to treat you" (Scott and Seglow, 2007). On the other hand, some studies (Taylor et al., 2006; Hoffman, 1981) state that altruis $m$ is based on genetics. Accordingly, the individual may have a tendency to exhibit genetically selfish behaviours, as well as biological predispositions to exhibit altruistic behaviours. Finally, some research in the literature emphasizes helping behaviours including social norms of societies such as responsibility, reciprocity and honesty as altruism (Taylor et al, 2006). 
We approach altruism from a different perspective in this study and we investigate its sociodemographic and socioeconomic determinants during COVID-19 pandemic.

\section{Data and Methods}

In this study, we aim to reveal the factors affecting altruism levels of the individuals. We exploit multivariate linear regression in a quantile regression design to identify the factors affecting altruism. We use secondary data that was obtained for our previous study on voluntary self-isolation during the COVID-19 pandemics. The data was collected virtually through questionnaires in the period between 6-12 April 2020. It bears the information of 933 individuals living in Turkey those are selected according to snowball sampling. The questionnaire is formed by three sections in the total. First section examines socio-demographic and socioeconomic characteristics of the individuals. Second section collects the information about their behaviours in the epidemic process. The last section applies altruistic behaviour scale that is constructed and validated by Ersanl1 and Dogru Cabuker (2015) in Turkey. The scale bears 20 questions and its values vary from (-10) to 70. Higher scores of the scale imply better altruistic behaviour.

We perform multivariate linear regressions in a quantile regression design to detect the factors affecting altruism level at different points of altruism distribution ${ }^{1}$. We estimate the effects on the mean level of altruis $m$ as well as $10 \%, 25 \%, 50 \%, 75 \%$ and $90 \%$ quantiles of the distribution.

It is possible to show the quantile regression model in the study with the following formula:

$$
Y_{A L_{i} \delta}=\alpha+\beta_{k}(\delta) X_{k}+u_{i}
$$

According to formula, $Y_{A L, \delta}$ is the outcome, the level of altruism (AL) in $\delta$ quantiles of the distribution, $\alpha$ is the constant, $X_{k}$ is the vector of explanatory variables, $\beta_{k}(\delta)$ depicts the estimated effects on altruism in the related quantile and finally $u_{i}$ is the error term.

We include a bunch of socio-demographic and socioeconomic variables such as age, gender, marital status, education level, inc ome le vel,

\footnotetext{
${ }^{1}$ Since the altruism level cannot be higher than 70 , the dependent variable was thought to be limited from the top therefore, Tobit (discrete) regression estimate was also made in the study. Because the marginal impacts obtained by the Tobit regression estimation are not different from the multivariate linear regression estimates, the related estimate is not presented in the study.
} 
the place of residence and the number of siblings into the models. Age, income and the number of siblings are continuous; while gender, marital status, education and place of residence are in categoric designs.

Since the literature suggests that altruism is based on religious beliefs originally, we consider religious sensitivity of the individuals in the models. Religious sensitivity is measured by a binary variable questioning deciding according to religious norms in every decision in daily life. Finally, considering the risk of the spread to others and the fact that some groups are more vulnerable to COVID-19 infection (Qiu, Shen and Wang, 2020; Zhang, Zhu and Xie, 2020; Pfefferbaum and North, 2020), we control for the case of living with those are vulnerable to COVID-19 infection (i.e., elderlies, pregnant and those have chronic diseases).

Table 1. Information on Dependent and Independent Variables Used in Models

\begin{tabular}{|c|c|c|c|c|c|}
\hline Variable & Statement & $\mathbf{N}$ & Mean & Min. & Max. \\
\hline Age & Age & 933 & 26.625 & 20 & 65 \\
\hline Female & Gender $=$ Female & 933 & 0.723 & 0 & 1 \\
\hline Male & Gender $=$ Male (Reference Category) & 933 & 0.277 & 0 & 1 \\
\hline Married & Marital Status = Married & 933 & 0.307 & 0 & 1 \\
\hline Single & $\begin{array}{l}\text { Marital Status = Not Married (Reference } \\
\text { Category) }\end{array}$ & 933 & 0.693 & 0 & 1 \\
\hline Sibling & Number of Siblings & 932 & 3.494 & 1 & 14 \\
\hline $\begin{array}{l}\text { Religious } \\
\text { Judgment }\end{array}$ & $\begin{array}{l}\text { Decision Making According to Religious } \\
\text { Judgments }\end{array}$ & 932 & 0.769 & 0 & 1 \\
\hline Education 1 & $\begin{array}{l}\text { A Lower Level of Education than } \\
\text { University }\end{array}$ & 933 & 0.411 & 0 & 1 \\
\hline Education 2 & $\begin{array}{l}\text { University } \quad \text { Graduate } \quad \text { (Reference } \\
\text { Category) }\end{array}$ & 933 & 0.463 & 0 & 1 \\
\hline Education 3 & $\begin{array}{l}\text { A Higher Education Level from } \\
\text { University }\end{array}$ & 933 & 0.124 & 0 & 1 \\
\hline Income & Monthly Income (Turkish Lira) & 932 & 5224.887 & 0 & 100000 \\
\hline Elderly & Living with an Elderly Person & 932 & 0.169 & 0 & 1 \\
\hline Pregnant & Living with a Pregnant Person & 932 & 0.169 & 0 & 1 \\
\hline Chronic & $\begin{array}{l}\text { Living with a Person Having Chronic } \\
\text { Illness }\end{array}$ & 932 & 0.413 & 0 & 1 \\
\hline
\end{tabular}




\begin{tabular}{llllll} 
Village & Living in the Village & 932 & 0.105 & 0 & 1 \\
Town & Living in the Town & 932 & 0.422 & 0 & 1 \\
City Centre & $\begin{array}{l}\text { Living in the City Centre (Reference } \\
\text { Category) }\end{array}$ & 932 & 0.472 & 0 & 1 \\
\multirow{2}{*}{$\begin{array}{l}\text { Metropolitan } \\
\text { Altruism }\end{array}$} & Living in the Metropolitan & 933 & 0.795 & 0 & 1 \\
\hline \hline
\end{tabular}

\section{Results}

We estimate the effects on the altruism levels of the individuals with multivariate linear regressions in a quantile regression design. The factors affecting altruism level on the mean value as well as on the $10 \%, 25 \%, 50 \%$, $75 \%$ and $90 \%$ quantiles of altruism distribution are revealed. The findings are presented in Table 2. The first column of the table illustrates the variables used in the models. The second column demonstrates the estimated effects on the mean level of altruism, while the third and the following columns show the estimated effects on the $10 \%, 25 \%, 50 \%, 75 \%$ and $90 \%$ quantiles of altruism distribution, respectively.

The mean altruism level of the respondents is about 55 . Therefore, we understand that the altruism level of the society is already high. We believe, this may explain observing statistically insignificant estimates for some variables in the models.

For the effects at the mean, we observe that gender, having siblings, having religious sensitivities and the place of residence have significant impacts on altruism level. On the other hand, age, marital status, education and income do not have significant associations with altruism level. Surprisingly, no significant effects of living with people vulnerable COVID19 are observed on altruism level.

Women have 3 points higher altruism level on average implying that women are more altruistic compared to men. One unit increase in the number of siblings a person has are associated with the increases in the level of altruism by about 0.5 points. Therefore, it is understood that as the number of siblings an individual has increased, the level of altruism increases. The altruism level of those who make their decisions in their daily lives according to religious judgments is approximately 5 points higher th an those who do not. In other saying people with religious sensitivities are more altruistic compared to their fewer religious counterparts. Finally, the altruism level of the people living in town is 1.5 points higher than the people living 
in city centre. It means that the people living in town are more altruistic in comparison with their counterparts living in city centre.

As for the effects on different quantiles of altruism, it is understood that gender has a significant impact at lower altruism levels. Further, as altruism level increases, gender differences decrease and disappear.

Table 2. Quantile Regression Results

\begin{tabular}{|c|c|c|c|c|c|c|}
\hline Variables & Mean & 0.1 & 0.25 & 0.5 & 0.75 & 0.9 \\
\hline Age & 0.035 & 0.021 & -0.008 & 0.043 & 0.035 & 0.053 \\
\hline & & $6.017 * *$ & & & & \\
\hline Female & $3.361 * * *$ & $*$ & $3.313 * * *$ & $4.379 * * *$ & $1.770 *$ & -0.103 \\
\hline Male & 0.482 & 0.834 & -0.445 & 0.222 & 0.359 & 1.073 \\
\hline Sibling & $0.437 * * *$ & $0.949 * *$ & $0.595 * *$ & $0.628 * * *$ & 0.068 & -0.264 \\
\hline $\begin{array}{l}\text { Religious } \\
\text { Judgment }\end{array}$ & $4.636 * * *$ & $\begin{array}{l}5.625 * * \\
*\end{array}$ & $5.591 * * *$ & $4.490 * * *$ & $4.382 * * *$ & $2.735 * * *$ \\
\hline Education 1 & 0.191 & 1.360 & 0.258 & 0.431 & -0.145 & -0.309 \\
\hline Education 2 & -0.309 & 1.478 & 0.778 & -1.573 & 0.519 & 0.942 \\
\hline Income & 0.001 & 0.001 & 0.001 & 0.001 & 0.001 & 0.001 \\
\hline Elderly & 0.183 & 0.421 & 0.511 & 0.165 & 0.332 & 0.812 \\
\hline Pregnant & 0.605 & 1.386 & 0.419 & -0.767 & 1.337 & 0.786 \\
\hline Chronic & 0.186 & -0.790 & 0.566 & -0.485 & 0.235 & -0.627 \\
\hline Village & 0.654 & 2.739 & 1.405 & -0.120 & 0.443 & 0.132 \\
\hline Town & $1.519 * *$ & 1.690 & $3.390 * * *$ & -0.027 & 0.315 & 0.423 \\
\hline Metropolitan & -0.277 & 1.673 & 0.757 & -0.640 & -1.194 & -0.625 \\
\hline Constant & $\begin{array}{l}45.638 * * \\
*\end{array}$ & 27.133 & $\begin{array}{l}37.969 * * \\
*\end{array}$ & $\begin{array}{l}47.065 * * \\
*\end{array}$ & $\begin{array}{l}56.207 * * \\
*\end{array}$ & $\begin{array}{l}\text { 63.178** } \\
*\end{array}$ \\
\hline $\mathbf{N}$ & 932 & 932 & 932 & 932 & 932 & 932 \\
\hline (Pseudo) r2 & 0.09 & 0.09 & 0.07 & 0.05 & 0.04 & 0.04 \\
\hline
\end{tabular}

***: $\mathrm{p}<0.01 ; * *: \mathrm{p}<0.05 ; *: \mathrm{p}<0.1$

\section{Discussions}

In this study, we aim to reveal the factors affecting altruism le vels of the individuals. We exploit the data of our previous study on voluntary selfisolation during the COVID-19 pandemic. The data bears sociodemographic, socioeconomic and behavioural and altruistic characteristics of 933 people 
living in Turkey. We perform multivariate linear regression in a quantile regression design to estimate the effects of interest. The results indicate that the altruism level of Turkish society is already high. We observe that gender, having siblings, having religious sensitivities, and the place of residence have significant impacts on altruism level.

Women are more altruistic than men, although as the level of altruism increases the differences in altruism levels tend to decrease or even disappear. As the number of siblings a person has increases, the level of altruism increases. We believe that the increase in the number of siblings improves the phenomenon of sharing and leading to observe such effect. The observed effect of the number of siblings disappears at higher altruism levels.

Having religious sensitivities significantly increases the altruism level of individuals. The findings support the literature (Monroe, 1996: 121) that ties the basis of altruism to beliefs and suggests that religion and morality increase altruism.

Additionally, we find that the people living in the district are more altruistic than the people living in the city centre. Considering higher workload and relatively fast flow of daily life in the city centres we believe that a relatively calm life in the district allows people to think of (each) others.

Surprisingly, living with people vulnerable to COVID-19 infection (i.e., elderlies, pregnant and those with chronic diseases) seems in effective on altruism level. We believe that higher altruism levels of the re spondents already lead to observe insignificant estimates regarding vulnerability.

Ethics Declaration: Ethics committee decision was not taken because there was no ethical obligation when the data was collected. 


\section{References}

Khalil, E. L. (2004). What is altruism?. Journal of economic psychology, 25(1), 97123.

Leeds, R. (1963). Altruism and the Norm of Giving. Merrill-Palmer Quarterly of Behaviour and Development, 9(3), 229-240.

Levey-Bruhl, L. (1970). August Comte Felsefesi ve Sosyolojisi (Z.F. Fındıkçığlu Çev.). Fakülteler Matbaası.

Lishner, D. A., \& Stocks, E. L.(2009). Altruism. In S. J. Lopez (Eds.), The Encyclopedia of Positive Psychology (pp. 32-38). West Sussex: Blackwell Publishing Ltd.

Mateer, N. H. \& Willover, D. J. (1994). Teacher Altruism: Implications for Administrators, Pennsylvania Educational Leadership, 13(2): 29-31.

Monroe, K. R. (1996). The Heart of Altruism: Perceptions of Common Humanity. New Jersey: Princeton University Press.

Moore, C., ve Frye, D. (1991). The Acquisition and Utility of Theories of Mind. In Frye D. \& Moore C. (Eds.), Children's Theories of Mind: Mental States and Social Understanding (pp. 1-14). Hillsdale, NJ: Lawrence Erlbaum.

Organ, D. W., Podsakoff, P. M., ve MacKenzie, S. B. (2005). Organizational Citizenship Behaviour: Its Nature, Antecedents, and Consequences. Sage Publications.

Pfefferbaum, B., \& North, C. S. (2020). Mental health and the Covid-19 pandemic. New England Journal of Medicine. DOI: 10.1056/NEJMp2008017

Podsakoff, P.M. ve Mac Kenzie, S.B. (1994) Organizational Citizenship Behaviours And Sales Unit Effectiveness, Journal of Marketing Research, 31 (3): 351 363.

Qiu, J., Shen B., M., Wang, Z., Xie, B. \& Xu, Y. (2020). A nationwide survey of psychological distress among Chinese people in the COVID-19 epidemic: implications and policy recommendations. General psychiatry, 33(2): 1-3. doi: $10.1136 /$ gpsych-2020-100213

Ross, W.D. (1993). Aristoteles, (A. Arslan, Tran.). İzmir, Ege University Publications.

Scott, N. ve Seglow, J. (2007). Altruism. New York: Open University Press.

Smith, C. A., Organ, D. W., \& Near, J. P. 1983. Organizational citizenship behaviour: Its nature and antecedents. Journal of Applied Psychology, 68 (4): 655-663.DOI: 10.1037/0021-9010.68.4.653

Taylor, S. E., Peplau, L. A., \& Sears, D.O. (2006). Social psychology (12th edition). New Jersey: Pearson Education, Inc.

World Health Organization, (2020a). Pneumonia of Unknown Cause-China). Accessed in: https://www.who.int/csr/don/05-january-2020-pneumonia-ofunkown-cause-china/en/

World Health Organization, (2020c). Critical Preparedness, Readiness and Response Actionsfor COVID-19: Interim Guidance. 24 June 2020. 
146 Hasan Giray ANKARA-Hakan DEĞERLi-Havvana DEĞERLI/ KAFDAĞI, Cilt:6, Sayı 2, 2021, 137-146

World Health Organization, (2020b). Accessed in: https://www.who.int/emergencies/disea ses/novel-coronavirus-2019/questionand-answers-hub/q-a-detail/q-a-coronaviruses

Zettler, I., Hilbig, B E. (2010). Attitudes of Selfless: Explaining Political Orientation with Altruism. Personality and Individual Differences, 48(3), 338-342. https://doi.org/10.1016/j.paid.2009.11.002

Zhang L, Zhu F, Xie L, Wang C., Wang J ... Zhou M. (2020). Clinical characteristics of COVID-19-infected cancer patients: a retrospective case study in three hospitals within Wuhan, China. Ann Oncol. (31)7: 894-901. doi:10.1016/j.annonc.2020.03.296 